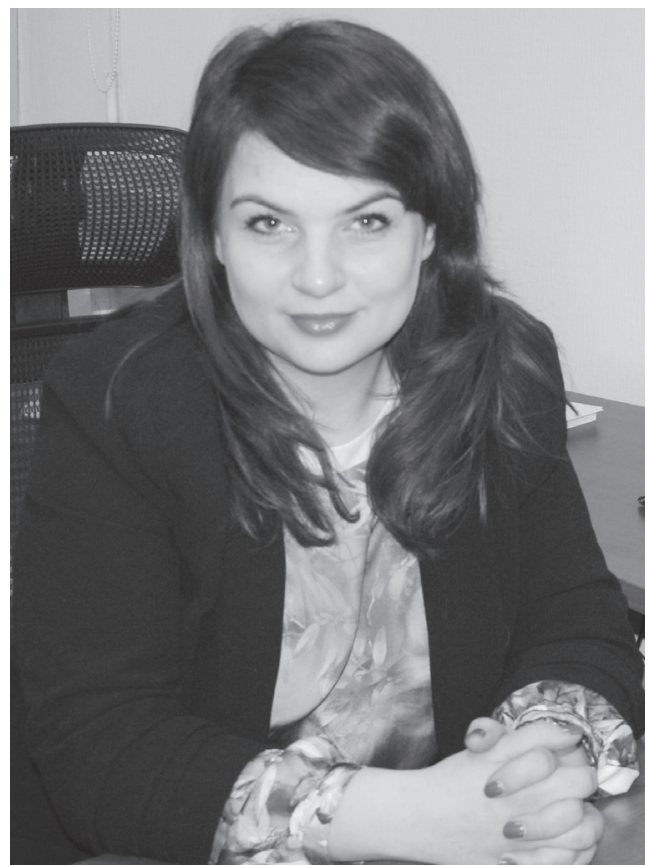

UDC 35.01; 23.04.44

DOI: https://doi.org/10.32689/2617-

2224-2019-17-2-206-216

\section{Marusheva Oleksandra Anatoliivna,}

PhD in Law, Associate Professor of the Department of Public Administration, Doctoral research scholar of the Department of Public Administration; Interregional Academy of Personnel Management, 03039, Kyiv, Str. Frometivska, 2, tel.: +38 (067) 8959485 , e-mail:marusheva.o@gmail.com

ORCID: 0000-0001-9126-4674

Марушева Олександра Анатолї̈на, кандидат юоидичних наук, дочент кафедри публічного адміністрування, здобувач наукового ступеня доктора наук з державного управління, Міжрегіональна Академія управління персоналом, 03039, м. Київ, вул. Фрометівська, 2, тел.: +38 (067) 89594 85, e-mail: marusheva.o@ gmail.com

ORCID: 0000-0001-9126-4674

Марушева Александра Анатольевна,

кандидат юридических наук, доцент кафедры публичного администрирования, соискатель научной степени доктора наук по государственному управлению, Межрегиональная Академия управления персоналом, 03039; г. Киев, ул. Фрометовская, 2, тел.: +38 (067) 89594 85, e-mail: marusheva.o@gmail.com

ORCID: 0000-0001-9126-4674

\title{
STRATEGIES FOR REGULATION OF SOCIO-ECONOMIC RELATIONS IN CONSTRUCTION
}

Abstract. The article clarifies that a concept is the basis of the methodological fundament of government regulation of socio-economic relations in any field. In order to distinguish between modern concepts, the peculiarities of socio-economic relations in the field of construction and the disadvantages of state regulation of this sphere are determined first of all. Taking into consideration the considered aspects, it was discovered that in recent years, the new concepts of state regulation of social and economic relations in construction have become widespread: the neoinstitutional concept; "FutureStep" concept; the concept of "Activating State"; the concept of Policy Networks; Micro Strategy concept; concept of "Management by Objectives"; Change concept; the concept of a Public-Private Partnership. Each 
of the above mentioned strategies provides for a flexible mechanism for government regulation of socio-economic relations with the consistent improvement of its interaction with various spheres of state activity. It is proved that applying the concepts and strategies given in the article contributes to the impact on the speed of economic processes, the efficiency of decisions in the aspect of government regulation of the construction industry. In particular, the article considers strategies, combining different approaches and tools that allow more effective coordination of processes and management entities, more focus on the aspect of sustainable development, allows to solve urgent problems effectively, stimulate a significant increase in labor productivity in the industry, to carry out effective management in conditions of unpredictable factors, and for instance, the concept or strategy of a public-private partnership creates an opportunity to focus on planning and ensuring the implementation of large-scale construction projects.

Keywords: concept, concept of regulation, socio-economic relations, construction, construction industry, government regulation.

\section{СТРАТЕГІї РЕГУЛЮВАННЯ СОЦІАЛЬНО-ЕКОНОМІЧНИХ ВІДНОСИН У БУДІВНИЦТВІ}

Анотація. 3'ясовано, що основою методологічного базису державного регулювання соціально-економічних відносин у будь-якій галузі є концепція. Для виокремлення сучасних концепцій та стратегій насамперед визначено особливості соціально-економічних відносин у сфері будівництва та недоліки державного регулювання даної сфери. 3 огляду на розглянуті аспекти, виявлено, що останніми роками значного поширення набувають новітні концепції та стратегії державного регулювання соціально-економічних відносин у будівництві, а саме: неоінституційна концепція; концепція "FutureStep"; концепція “активізуючої держави”; концепція політичних мереж; мікростратегічна концепція; концепція "управління за результатами”; концепція змін; концепція або стратегія державно-приватного партнерства. Кожна з наведених стратегій передбачає забезпечення гнучкого механізму державного регулювання соціально-економічних відносин з послідовним удосконаленням його взаємодії з різними сферами державної діяльності. Обгрунтовано, що застосування наведених концепцій та стратегій сприяє посиленню впливу на швидкість економічних процесів, підвищенню ефективності рішень в аспекті державного регулювання будівельної галузі. Зокрема, розглянуті стратегії, поєднуючи різні підходи та інструменти, дають можливість ефективно координувати процеси та суб'єкти управління, більше фокусуватись на аспекті стійкого розвитку, дозволяе ефективно вирішувати нагальні суспільні проблеми, стимулювати істотне підвищення продуктивності праці в галузі, здійснювати ефективне управління в умовах непередбачуваних чинників (наприклад, концепція або стратегія державно-приватного партнерства створює можливість зосередитись на плануванні та забезпеченні виконання великомасштабних будівельних проектів). 
Ключові слова: стратегія, концепція регулювання, соціально-економічні відносини, будівництво, будівельна галузь, державне регулювання.

\section{СТРАТЕГИИ РЕГУЛИРОВАНИЯ СОЦИАЛЬНО- ЭКОНОМИЧЕСКИХ ОТНОШЕНИЙ В СТРОИТЕЛЬСТВЕ}

Аннотация. Установлено, что основой методологического базиса государственного регулирования социально-экономических отношений в любой отрасли является концепция. Для выделения современных концепций и стратегий прежде всего определены особенности социально-экономических отношений в сфере строительства и недостатки государственного регулирования данной сферы. Учитывая рассмотренные аспекты, выявлено, что в последние годы широкое распространение приобретают новейшие концепции и стратегии государственного регулирования социально-экономических отношений в строительстве: неоинституционная концепция; концепция “FutureStep"; концепция “активизирующего государства”; концепция политических сетей; микростратегическая концепция; концепция “управления по результатам”; концепция изменений; концепция или стратегия государственно-частного партнерства. Каждая из приведенных стратегий предусматривает обеспечение гибкого механизма государственного регулирования социально-экономических отношений с последовательным совершенствованием его взаимодействия с различными сферами государственной деятельности. Обосновано, что применение приведенных концепций и стратегий способствует усилению влияния на скорость экономических процессов, способствует повышению эффективности решений в аспекте государственного регулирования строительной отрасли. В частности, рассмотренные концепции и стратегии, сочетая различные подходы и инструменты, позволяют более эффективно осуществлять координацию процессов и субъектов управления, в большей степени фокусироваться на аспекте устойчивого развития, эффективно решать насущные общественные проблемы, стимулировать существенное повышение производительности труда в отрасли, осуществлять эффективное управление в условиях непредсказуемых факторов (например, концепция или стратегия государственночастного партнерства дает возможность сосредоточиться на планировании и обеспечении выполнения крупномасштабных строительных проектов).

Ключевые слова: стратегия, концепция регулирования, социально-экономические отношения, строительство, строительная отрасль, государственное регулирование.

Problem statement. Significant changes in the environment (intensification of information flows, the development of telecommunications, finance) which took place at the turn of the $20^{\text {th }}-21^{\text {st }}$ centuries changed the role of space and time in the management and activities of industrial and 
economic enterprises; and contributed to the development and formation of new concepts and management models, which are reflected in the public management of the construction industry. In practice, there took place the establishment of a new economic formation, flexible and mobile, which is controlled by economic flows capable to change the spheres of activity and consumption of wealth. In other words, it shows a change in the modern sociodemocratic paradigm of governance to one that is more responsive to the demands of the information society, based on pluralism, new needs and values, methods, etc. Consequently, there was a need to define new concepts and strategies of socio-economic relations in the field of construction.

Analysis of recent research and publications. Leading scientists and researchers, such as I. Brailovskyi, O. Vinnyk, O. Haman-Holutvynova, A. Dehtiarev, O. Zalunina, K. Listratov, I. Malkovska, V. Melko, K. Pavliuk, L. Shulhina, L. Shutenko, etc., were engaged in researches in this sphere. At this stage, special attention is required to the issue of modern concepts of regulation of socio-economic relations.

Formulation of the objectives of the article. The objective of this article is to analyze modern strategies and concepts of regulation of socio-economic relations in construction and their controlling influence.

Presentation of the basic material. A concept is the basis of the methodological foundation of government regulation of socio-economic relations in any industry. The scientific concept as a theoretical imperative shall both reflect ways of understanding the pro- cesses and phenomena occurring and explore ways to solve the identified problems, offer directions of economic growth and development. Any scientific concept reflects the most important provisions that harmonize and link theoretical knowledge with practical experience. The principles and approaches of a certain scientific concept can be implemented as a certain strategy of government regulation of socioeconomic relations.

Analysts note that construction is a priority sector of economic development, but in the crisis it is necessary to pay special attention to the study of factors affecting the construction sector of the country [1]. At the same time, one of the decisive factors influencing the construction industry is the efficiency of government regulation. The efficiency of the construction industry depends on the mechanisms of government regulation. Government regulation of construction should be considered as a set of measures of state bodies of legislative, executive and control nature aimed at stabilization and adaptation of the current economic system to the changing conditions of development of the country (region) [2].

The main stakeholders of socioeconomic relations in construction can perform various functions and, depending on this, receive the appropriate name, namely [3, p. 536]:

1) investor is an investment entity in the field of capital construction which decides on investing of internal, borrowed or obtained funds (investments) in the investment projects belonging to the fixed assets;

2) client is an investment entity in the field of capital construction, pro- 
cures from the contractor design and survey, construction and related works. The role of the client can be performed by the investor himself or his authorized person, including consulting and/or engineering organization specializing in construction;

3 ) contractor is an organization or an individual entrepreneur, who on a contractual basis undertakes to perform design and survey, construction and related work at the order of the client for a fee.

Features of socio-economic relations in the field of construction are determined by the products of construction - commissioned production facilities, non-production facilities and infrastructure, including the necessary equipment for their operation. Features of technical and economic character are as follows [4]:

- heterogeneity and originality of the products, which differ in the nature of production and functional purpose, which requires individual approaches to each facility under construction, taking into account its purpose and use, construction site, client's requirements;

- real estate of construction projects (as a rule, location of a construction site coincides with a place of usage), which requires mobility of means of production, since in the process of construction all means of production and labor are to be moved on the site, depending on the stages of the technological cycle, and this significantly increases the production costs associated with transportation, installation, dismantling of equipment, construction machines and mechanisms, transport of labor, etc.;

- the impact of climatic conditions on the production process which re- quires for each case specific design and layout solutions, changes in wages of builders depending on the conditions of work, season, temperature, etc.;

- influence of the time factor, which is manifested in a fairly long production cycle which, in its turn, determines the long return period of capital investments and the presence of work in progress;

- a high level of one-time costs required to start the production cycle and the withdrawal of funds from circulation for a considerable period, which means their actual freezing up to a certain time;

- specific commodity relations between the manufacturer and the consumer of construction products arising before the start of the production process and which are implemented through a system of contractual relations.

At the same time, the functioning of the state is associated with transaction costs. And they are the more the larger number of transactions are made by the state as a guarantor of the contract terms. The more active role of the state is in the specifying and protecting property rights, the more complex the internal structure of the administration is and the more information circulating in it is distorted. Therefore, the state "failures" should be taken into account along with the "failures" of the market, which today can be attributed to [2]:

- the discrepancy between revenues and expenses - it is much more difficult to turn the state into a bankrupt even if it fails to fulfill its obligations;

- the lack of clear criteria to efficiency of government actions: government agencies substitute them with 
self-developed standards, and then the government actions are evaluated by these self-established criteria (increase in revenue, expansion of state control etc.);

- the high probability of achieving results that are different from the set tasks: the growth of information, monitoring and controlling costs that accompany the development of the state creates the prerequisites for the deviation of the implemented tasks from the set ones;

- unbalanced distribution of enterprise resources, therefore, one has to choose between two imperfect alternatives: the distribution of property rights is based on market exchange, which operates without expenses, with private performance guarantees and the transfer of control over the exchange of powers to the state, which acts in the interests of the parties to the contract.

Taking into account the considered aspects, it should be noted that in recent years the new concepts and strategies of government regulation of socio-economic relations in construction have become widespread, namely:

- Neo-Institutional concept;

- FutureStep concept;

- Activating State concept;

- Policy Networks concept;

- Micro Strategy concept;

- Management by Objectives concept;

- Change concept;

- Public-Private Partnership concept or strategy.

Each of the above mentioned strategies provides for a flexible mechanism of government regulation of socio-economic relations with the consistent im- provement of its interaction with various spheres of government activity.

Speaking about the essence of the new institutional theory and its practical value in the field of public administration research, it focuses on the "analysis of transaction costs", forming an original theoretical basis for solving the issue of the effectiveness of various institutional forms and interaction coordination between different management entities. According to representatives of this theory, taking into account transaction costs, it is possible to achieve the greatest efficiency of public management [5].

The FutureStep concept is a new strategic management process helping companies, especially adaptive large multinational corporations, make company characteristics, such as flexibility and responsiveness, an integral part of every aspect of their operations. This approach to strategic management is a modular tool. Its parts can be used both independently and within the framework of the complete program as a guide to strategic decision making. The main focus is on what the organization can do today to increase its ability for adequate operation and sustainable development of socio-economic relations in the future [6].

Within the Activating State concept, the tasks of state administration bodies are determined in the course of public discussion, and society and the state develop cooperation and allocate responsibilities. The state initiates the processes of social problems settlement and acts as an intermediary; limits liability of citizens within this framework. Thus, initiation, activation and stimulation are the most important functions 
of the state. The Activating State model provides for formation and study of the state in four dimensions [7]:

- the state as a production and services guarantor;

- the state as a service provider to society, if it is dictated, for example, by security issues or if the state can do it at a lower cost than other actors;

- the state as an institution that creates a framework of social activity and creates conditions for citizens to solve problems;

- the state as an institution supervising socio-economic activities.

The main element of the following concept is the concept of "Policy Network" [8]. In general terms, the network is understood as a system of government and non-government actors in a certain sphere of policy that interact on the basis of resource dependence in order to reach agreement on a certain issue, using formal and informal norms [9]. It should be noted that in accordance with this concept, socioeconomic relations are no longer controlled exclusively by state authorities, the instruments are scattered, and the material resources that are the object of these relations are distributed among the various participants in these relations. The function to coordinate participants of socio-economic relations no longer belongs to the central management, but is formed by purposeful interactions between individual market participants.

Another concept was "Micro Strategy as an alternative to long-term strategic planning in uncertain times", which was developed by D. Logan and H. Fischer-Wright. Having studied data on the activities of about 24,000 people in almost 10 years, the authors concluded that the most successful were those leaders who used micro strategies (short-term strategies) in their work, moving from one short-term objective to another. Micro strategies are formed into a certain system of more or less important plans. Instead of pre-planning all future steps, it is better to break them down into micro strategies. This will allow the organization to learn and adjust its actions in the process of achieving the global goal [10].

The concept of Management by Objectives (MBO), which today is experiencing its "revival", was developed in the mid-1960 by an American scientist P. Drucker, one of the most famous specialists in the field of management and marketing. He believed that this concept is a method of improving the efficiency of the organization, according to which the activities of any employee is evaluated not by the process, but by the result, if the result is understood as the achievement of the objective, the task. The practice of using the MBO has showed that P. Drucker was right: the main benefits from the implementation of this system in the organization is to increase productivity through clear guidelines for each employee and increase motivation of the staff through its participation in setting its own objectives [5].

The Change concept is based on the fact that an effective formal strategy must contain the main chains, the most essential elements of restrictive policies, and the sequence of basic actions. Effective strategies are developed around several key concepts and directions of development of socio-economic relations. The strategy deals not only 
with unpredictable factors but also with unknown ones. In a complex organization, there should be a hierarchy of interrelated and supportive strategies between the various actors in the relationship [11].

The Public-Private Partnership concept or strategy mainly refers to the coordination of objectives and ensuring a balance of interests of the state and business in the framework of socio-economic projects aimed at achieving common benefits. In this interpretation, PPP includes all forms of cooperation between the state and the private sector not only in the economy, but also in other spheres of public life - politics, culture, science [12].

Depending on the interpretation of the essence of the partnership, its basic features include the following [13]:

- the parties of public-private partnership are the state and business, as well as society;

- interaction between the parties is fixed on a formal, legal basis;

- interaction between the parties is equal;

- a public-private partnership is clearly publicly and socially oriented;

- in the course of interaction based on a public-private partnership the resources and contributions of the parties are consolidated, combined;

- financial risks and costs, as well as the results obtained, are distributed among the parties in predetermined proportions.

At the same time I. Brailovskyi, studying a public-private partnership, determines that the potential benefits of using such form of economic interaction as a public-private partnership may consist of the fact that this format of business-government relations can provide [14]:

- greater efficiency, as well as time savings in the implementation of pro jects and works, through the using by partnership members their strengths;

- diversity of approaches to the design and further implementation of projects through the use of different methods and increasing the number of options;

- higher quality of economic and management decisions in the implementation of joint projects, which is ensured by the qualification of business representatives and the most complete consideration of social needs and social significance, which is provided by the representatives of governing bodies;

- integration of business entities into public life due to their direct involvement in the implementation of socially significant projects;

- quality improvement of goods and services by establishing higher level of state control;

- reduction of social tension and negative attitude to business on the part of the population by recognizing its contribution to solving social problems.

Application this form of interaction between the state and the private sector becomes common mainly in those construction projects where there is a need and a number of opportunities to solve large-scale problems of the socioeconomic sphere.

Conclusions and prospects for further research. Eight concepts and strategies of regulation of socio-economic relations in construction were defined. Summarizing the abovementioned, it can be assumed that the con- 
sidered concepts and strategies in the consideration of the modern model of government regulation of socio-economic relations in the construction industry enables development of a theoretical model of the object under study, allows to form a systematic approach to research in the field of construction, as well as to choose an effective method for solving these issues. An important measure in solving socio-economic problems in the construction industry is the use of regulatory frameworks that can affect the speed of economic processes, improve the efficiency of decisions in the aspect of state regulation, as well as change the possible gap between the existing differences. The complex issue of more efficient application of the concepts of government regulation of socio-economic relations in construction requires further research.

\section{REFERENCES}

1. Zalunina O. M. (2014). Rozvytok budivelnoho sektoru Ukrainy za ostanni roky [Development of the building sector of Ukraine in recent years]. Naukovyi visnyk Khersonskoho derzhavnoho universytetu. Seriia: Ekonomichni nauky - Scientific Bulletin of the Kherson State University. Series: Economic Sciences, 5, 1, 174-177 [in Ukrainian].

2. Shutenko L.M.(2011). Budivelna haluz yak obiekt derzhavnoho rehuliuvannia [Construction industry as an object of state regulation]. Synerhetychni aspekty formuvannia ekonomichnykh parametriv budivelnykh struktur $\mathrm{v}$ umovakh rynku - Synergetic aspects of formation of economic parameters of building structures in market conditions: Proceedings of International scientific practical internet confe- rence. (p. 5-6). Kharkiv: KhNAMH [in Ukrainian].

3. Vinnyk O. M. (2009). Hospodarske pravo [Economic Law]. (2 $2^{\text {nd }}$ ed., rew). Kyiv: Pravova yednist [in Ukrainian].

4. Melko V. L. (2017). Teoretychni pidkhody do derzhavnoho rehuliuvannia haluzi budivnytstva [Theoretical Approaches to State Regulation of the Construction Industry]. Derzhavne upravlinnia - Public Administration, 1 (57), 61-68 [in Ukrainian].

5. Malkozskaya I. A. (2006). Transformatsiya gosudarstva i evolyutsiya publichnogo administrirovaniya $\mathrm{V}$ usloviyakh globalizatsii [Transformation of the state and evolution of public administration in the conditions of globalization]. Vestnik Rossiyskogo universiteta druzhby narodov. Politologiya - Bulletin of The Peoples' Friendship University of Russia. Political science, 8, 27-43 [in Russian].

6. Shulhina L. M., Yukhymenko V. V. (2011). Suchasni kontseptsii stratehichnoho upravlinnia innovatsiinym rozvytkom pidpryiemstva [Contemporary Concepts of Strategic Management of Innovative Development of the Enterprise]. Marketynh i menedzhment innovatsii - Marketing and Management of Innovations, 3 (2), 79-84 [in Ukrainian].

7. Gaman-Golutvina O. (2007). Menyayushchayasya rol gosudarstva $\mathrm{v}$ kontekste reform gosudarstvennogo upravleniya: otechestvennyy i zarubezhnyy opyt [The changing role of the state in the context of public administration reforms: domestic and foreign experience]. Polis, 4, 46-58 [in Russian].

8. Degtyarev A. A. (2004). Prinyatie politicheskikh resheniy [Making political decisions]. Myiv: KDU [in Russian].

9. Listratov K. E. (2007). Upravlenie politicheskimi proektami: teoriya, metodologiya, realnaya politika [Po- 
litical Project Management: Theory, Methodology, Real Politics]. Vestnik Moskovskogo universiteta. Politicheskie nauki - Moscow University Bulletin. Political science -6 , 20-30 [in Russian].

10. Logan D., Fischer-Wright H. (2009). Micro strategies: The key to successful planning in uncertain times. Leader to Leader, 54, 45-52 [in English].

11. Mintzberg H., Brian Q. J., Ghoshal S. (1998). The Strategy Process. London; New York: Prentice Hall [in English].

12. Brailozskyi I. A. (2013). PEST-klasyfikatsiia ryzykiv derzhavno-pryvatnoho partnerstva [PEST-classification of risks of public-private partnership]. Skhid - East, 1(121), 15-19 [in Ukrainian].

13. Pavliuk K. V., Pavliuk S. M. (2010). Sutnist i rol derzhavno-pryvatnoho partnerstva $\mathrm{v}$ sotsialno-ekonomichnomu rozvytku derzhavy [The essence and role of public-private partnership in the socio-economic development of the state]. Naukovi pratsi Kirovohradskoho natsionalnoho tekhnichnoho universytetu. Ekonomichni nauky Scientific works of Kirovohrad national technical university. Economic Sciences, 17, 10-19 [in Ukrainian].

14. Brailovskyi I. A. (2014). Meta i zmist derzhavno-pryvatnykh partnerstv [Purpose and content of public-private partnerships]. Tekhnologicheskiy audit i rezervy proizvodstva - Technological audit and production reserves, 1 (5), 52-54 [in Ukrainian].

\section{СПИСОК ВИКОРИСТАНИХ ДЖЕРЕЛ}

1. Залуніна О. М. Розвиток будівельного сектору України за останні роки / О. М. Залуніна // Наук. вісн. Херсон. держ. ун-ту. Серія: Економічні науки. - 2014. - Вип. 5. -Ч. 1. C. $174-177$.
2. Шутенко Л. М. Будівельна галузь як об'єкт державного регулювання / Л. М. Шутенко // Синергетичні аспекти формування економічних параметрів будівельних структур в умовах ринку : матер. Міжнар. наук.-практ. інтернет-конф. / Харків, обл. держ. адм., Харків, нац. акад. міськ. госп-ва. - Харків : ХНАМГ, 2011. - C. 5-6.

3. Вінник О. М. Господарське право : навч. посіб. для студ. вищ. навч. закл. - 2-ге вид., змін. та допов. / О. М. Вінник. - К. : Правова єдність, 2009. - $766 \mathrm{c}$.

4. Мелко В. Л. Теоретичні підходи до державного регулювання галузі будівництва / В. Л. Мелко // Державне управління. - 2017. - № 1 (57). C. 61-68.

5. Мальковская И. А. Трансформация государства и эволюция публичного администрирования в условиях глобализации / И. А. Мальковская // Вестник Российского ун-та дружбы народов. Политология. 2006. - № 8. - С. 27-43.

6. Шульгіна Л. М. Сучасні концепції стратегічного управління інноваційним розвитком підприємства / Л. М. Шульгіна, В. В. Юхименко // Маркетинг i менеджмент інновацій. - 2011. - № 3 (2). - С. 79-84.

7. Гаман-Голутвина О. Меняющаяся роль государства в контексте реформ государственного управления: отечественный и зарубежный опыт / О. Гаман-Голутвина // Полис. 2007. - № 4. - C. 46-58.

8. Дегтярев A. А. Принятие политических решений / А. А. Дегтярев. - М. : КДУ, 2004. - 416 с.

9. Листратов К. Е. Управление политическими проектами: теория, методология, реальная политика / К. Е. Листратов // Вестник Моск. ун-та. Политические науки. 2007. - № 6. - C. 20-30. 
10. Dave Logan, Halee Fischer-Wright. Micro strategies: The key to successful planning in uncertain times [Текст] // Leader to Leader. - 2009. - № 54. P. 45-52.

11. Henry Mintzberg. The Strategy Process / Henry Mintzberg, James Brian Quinn, Sumatra Ghoshal. - 1998, p. $5-13$.

12. Брайловський I. A. РEST-класифікація ризиків державно-приватного партнерства / I. А. Брайловський / / Схід:аналітично-інформаційний фаховий наукометрич- ний журн. - 2013. - № 1 (121). C. 15-19.

13. Павлюк К. В. Сутність і роль державно-приватного партнерства в соціально-економічному розвитку держави / К. В. Павлюк, С. М. Павлюк // Наук. пр. Кіровоградського нац. технічного ун-ту. Економічні науки. - 2010. - Вип. 17. - С. 10-19.

14. Брайловський I. А. Мета і зміст державно-приватних партнерств / I. А. Брайловський // Технологический аудит и резервы производства. - 2014. - № 1 (5). - С. 52-54. 